\title{
FACTORS INFLUENCING KEY AUDIT MATTERS REPORTING IN THAILAND
}

\author{
MUTTANACHAI SUTTIPUN 1,*
}

Received: 29 July 2019 / Revised: 23 September, 4 October 2019 / Accepted: 10 October 2019 (C) 2020 Faculty of Business and Accountancy, University of Malaya. All rights reserved.

\begin{abstract}
A B S T R A C T
Research aim: This study investigated the level of Key Audit Matters (KAM) reporting in the annual reports of companies listed on the Stock Exchange of Thailand (SET) from 2016 to 2018, and examined the factors influencing KAM reporting.

Design/ Methodology/ Approach: Using annual reports from 2016 to 2018, 450 annual reports of 150 companies from the SET were sampled. Content analysis by word count and checklist was used to quantify the KAM reporting, while descriptive analysis, independent sample t-test, and multiple regression were used to analyse the data.

Research finding: The KAM reporting was 756.686 average words within 1.958 issues in corporate annual reports during the study period. There were significantly different levels of KAM reporting between SET100 and Non-SET100 companies as well as between audit rotation and non-audit rotation. Moreover, there was a significant positive influence of firm size and complexity on the level of KAM reporting, while profitability had a negative influence on the level of KAM reporting.
\end{abstract}

Theoretical contribution/ Originality: As the first longitudinal study of KAM reporting in Thailand, the study sheds light on the factors influencing mandatory KAM reporting.

Practitioner/ Policy implication: Investors can approach decision-making from the corporate characteristics affecting KAM reporting.

Limitation/ Implication: External audit characters are not included when considering the influence on KAM reporting.

Type of article: Research paper

Keywords: KAM reporting, Annual reports, Thailand Stock Exchange

JEL Classification: M40, M42

\section{Introduction}

Auditors use audit reports to communicate their opinions and concerns on the accuracy and completeness of financial statements and reports to corporate users such as investors, shareholders, creditors, standard setters, and regulators (Pratoomsuwan \& Yolrabil, 2018). However, users do not consider the report when decision-making thereby creating an (i) information gap and reducing the (ii) quality of communication (IAASB, 2011). Information gaps are a leading problem of audit reports because the information reported by auditors cannot satisfy corporate financial statement users who would like to have more specific information of each corporation when making decisions (Vanstraelen, Schelleman, Meuwissen, \& Hofmann, 2012).

Secondly, the quality of the audit report is a problem because the report provides similar disclosure across companies without the discretional reason of

\footnotetext{
${ }^{1}$ Department of Accountancy, Faculty of Management Sciences, Prince of Songkla University, Songkhla 90110,

*E-mail for corresponding author: muttanachai.s@psu.ac.th
} 
auditors (Porter, Hogartaigh, \& Baskerville, 2009). Bedard, Gonthier-Besacier, \& Schatt (2015) stated that audit reporting is not an effective means to communicate the important audit opinion to financial statement users. For example, IFAC (2015) found that investors were disappointed with the lack of quality and specificity of audit reporting. To increase quality and transparency of audit reports, since 2015, the International Auditing and Assurance Standards Board (IAASB, 2011) updated and improved traditional audit reporting under the International Standard on Auditing No. 701 'Communicating Key Audit Matters in the Independent Auditor's Report' to include KAM reporting.

KAM reporting is designed to enhance the communication value of audit reports by providing greater quality and transparency about the activities performed by the auditors. Several countries use KAM reporting such as United Kingdom, Australia, New Zealand, Singapore, and Malaysia. In Thailand, the Federation of Accounting Profession (FAP, 2016) of Thailand made KAM reporting mandatory for companies listed in the Stock Exchange of Thailand (SET) and the Market for Alternative Investment (MAI) since 2016. KAM reporting provides the most important auditing issues based on the auditor's discretion (FAP, 2016).

Moreover, KAM reporting is used to communicate with corporate financial statement users as well as regulators. KAM reporting helps accommodate the social expectations and values that change over time (Deegan, 2002). Companies have to act towards the society and community with socially acceptable behaviours which can enhance and sustain corporate successes (Islam \& Deegan, 2010). Companies will allow auditors to report KAM information in their annual reports if corporate top-management believe that information reporting depends on social and community expectations (De Villiers \& Van Standen, 2006).

Since KAM reporting is provided by the auditor's discretion, the extent of reporting is unknown in Thailand. Moreover, studies found that many Thai auditors still disclosed the same issues of KAM information in audit reports from 2016 to 2017 (Gunno \& Penawuthikul, 2018; Matheesuwapab, 2018). This could be because KAM reporting has become a boilerplate with technical language used. Even though KAM reporting is mandatory in Thailand's Stock Exchange of Thailand (SET) and the Market for Alternative Investment (MAI) since 2016, there are different levels of reporting between listed companies. For example, Pratoomsuwan and Yolrabil (2018) found that Thai companies listed in the SET100 provided higher levels of KAM reporting than non-SET100 and MAI companies. Moreover, Tangruenrat (2015) stated that the level of KAM reporting in Thailand is influenced by corporate characteristics. Howvere, Tangruenrat (2015) did not examine whether there was a relationship between corporate characteristics and KAM reporting. This can be determined using legitimacy theory because society and community have different expectations of corporate actions and activities. Thus, companies with higher expectations need to satisfy their society and community rather than companies with lower expectation. However, there is no evidence of factors influencing the level of KAM reporting in the annual reports of listed companies.

From the research problems above, this study (i) investigates the level of KAM reporting in the annual reports of companies listed on the Stock Exchange of 
Thailand (SET) from 2016 to 2018, and (ii) examines the relationship between corporate characteristics and level of KAM reporting. The two main questions are (i) what is the level of KAM reporting in the annual reports of companies listed on the Stock Exchange of Thailand (SET) from 2016 to 2018 and (ii) is there a relationship between corporate characteristics and the level of KAM reporting in the annual reports?

This study contributes theoretically by demonstration the factors influencing mandatory KAM reporting in Thailand using legitimacy theory. As for its practical contribution, top management will be able to use the results to understand and respond to business risks. For stakeholders, the study will help investors and shareholders assess the risk and complexity of companies they plan on investing, while regulators and standard setters will use the results as data to update and improve the regulations of the audit report. Moreover, they could evaluate the effect of KAM reporting on the information gap and auditors' behaviours.

This study begins with theoretical perspectives to explain how factors consisting of corporate characteristics influence on KAM reporting. Next, the literature review and hypothesis development are summarised and synthesised. Population and sample used, variable measurement, and data analysis are described along with the selected method. The findings are then discussions in reference to the research objectives before summarising and concluding the study.

\section{Theoretical Perspective}

Several theories explain why corporations provide information reporting such as stakeholder theory (Joshi \& Gao, 2009; Suttipun, 2018), signalling theory (Brown, DeJong, \& Levy, 2009; Pries \& Scott, 2018), agency theory (Tangruenrat, 2015; Srijunpetch, 2017), institutional theory (Bedard et al., 2015), and legitimacy theory (Gray, Kouhy, \& Lavers, 1995; Deegan, 2002; Islam \& Deegan, 2010). When these theoretical perspectives are compared with mandatory reporting in Thai context, legitimacy theory is used to explain the level of KAM reporting of listed companies from 2016 to 2018 and examine the factors (corporate characteristics) influencing KAM reporting in the annual reports of companies listed on the SET. The theory can explain how KAM reporting is used to reduce or close the legitimacy gap between corporate actions and social expectations (Islam \& Deegan, 2010).

The concept of social contract has given birth to legitimacy theory as an explanation of corporate actions, activities, and responses as a social member (Deegan, 2002; Gray et al., 1995). Successful companies will satisfy and serve social expectations because they are a part of society. However, Islam and Deegan (2010) mentioned that the expectations and values of society are not fixed, but change with time. Therefore, corporations have to provide actions, activities, and responses to meet social expectations including information disclosure. Like other information reporting, legitimacy theory can explain why companies would provide KAM reporting. This is because they have to act toward the society and community with socially acceptable behaviours that enhance and sustain the corporate successes (Deegan, 2002). Thus, reporting is used to legitimise corporate actions to their social expectations because the companies would like to show their 
compliance (Branco \& Rodrigues, 2008). Moreover, companies will allow auditors to provide KAM reporting in their annual reports if top management believes that the information reporting is demanded by society and community (De Villiers \& Van Staden, 2006).

There are several reasons as to why legitimacy theory can be used to explain the level of KAM reporting of listed companies from 2016 to 2018 and examine the factors influencing KAM reporting. Firstly, auditors use KAM reporting to respond to social and community expectations. Secondly, if there are differences in factors of corporate characteristics, KAM reporting can be provided in different extent and level either. Figure 1 illustrates the conceptual framework of the study.

\section{Literature Review and Hypothesis Development}

An audit is identified by the International Audit and Assurance Standard Board (IAASB) as an independent examination and expression of opinion on a firm's financial statements by an appointed auditor in accordance in terms of appointment and compliance with the relevant statutory and performance requirements. An audit report is the final report of audit assignment auditors issue to their clients containing a true and fair view regarding the firm's financial statements. Audit opinions on corporate financial statement are an important issue for stakeholders especially shareholders, investors, and regulators. Therefore, to increase quality and transparency of audit report, the International Auditing and Assurance Standards Board (IAASB, 2011) has updated and improved the traditional audit report under the International Standard on Auditing No. 701 'Communicating Key Audit Matters in the Independent Auditor's Report' to include KAM reporting.

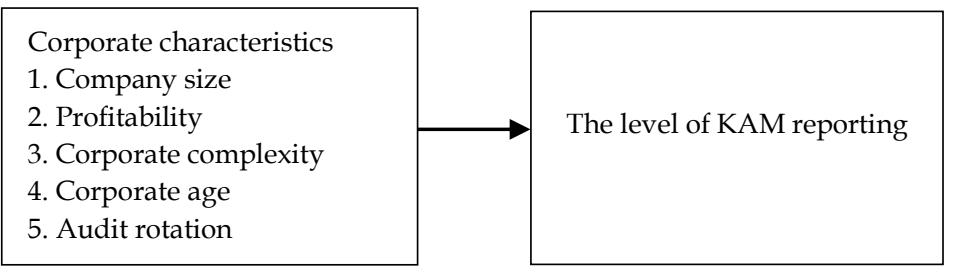

Figure 1. Theoretical Framework

KAM reporting enhances the communication value of audit reports by providing greater quality and transparency about what auditors have performed. Several countries use KAM reporting such as the United Kingdom, Australia, New Zealand, Singapore, and Malaysia. In Thailand, the Federation of Accounting Profession (FAP, 2016) of Thailand launched KAM reporting in a new version of audit reports and made it mandatory since 2016 for companies listed on the Stock Exchange of Thailand (SET) and the Market for Alternative Investment (MAI). KAM reporting details the most important auditing issues for a given period (FAP, 2016). Moreover, KAM reporting is used to communicate with corporate financial statement users as well as regulators. KAM reporting is based on auditors' opinions communicating financial and non-financial information to corporate users (stakeholders) about risks and possibilities such as revenue recognition, 
inventory, receivable and allowance, property valuation, asset impairment, investment and investment impairment, goodwill impairment, taxation, and provision (FAP, 2016). Thus, users can consider KAM reporting in annual corporate reports for a clearer understanding of firm risks and informed decisionmaking. This study examines the corporate characteristics influencing KAM reporting in Thailand from 2016 to 2018. Even though several studies explored corporate characteristics, the corporate characteristics influencing KAM reporting used in this study consisted of company size, profitability, corporate complexity, corporate age, and audit rotation. From company size, legitimacy theory is used to explain that larger companies are more interested in meeting social expectations compared to smaller companies (Taylor \& Liu, 2008). In studies of KAM reporting, Taylor and Liu (2008) and Velte (2018) found that company size positively influenced KAM reporting. Moreover, larger companies have more audit activities than smaller companies. Therefore, the level of audit reporting on larger companies tends to disclose more common than smaller companies (Velte, 2018). However, Boonyanet and Promsen (2018) found no relationship between corporate size and KAM reporting of companies listed on the Stock Exchange of Thailand (SET100 Group). Thus, to test the hypothesis from mixed evidence, this study hypothesises:

H1: There is a positive relationship between company size and the level of KAM reporting.

In terms of profitability, although several proxies have been used such as return on asset, return on equity, net profit, or firm value, this study chooses return on asset (ROA) (Ishak \& Abidin, 2018; Velte, 2018; Ousubcharoenchai, 2005). Unlike the positive influence of corporate size on KAM reporting, Velte (2018) and Ousubcharoenchai (2005) found a negative influence of profitability measured by ROA on KAM reporting. This is because when companies experienced loss or profit reduction, they were caused by the higher risk that affects audit reporting (Velte, 2018). It means auditors need to provide more information and disclosure of their opinions to corporate changes and risks. On the other hand, if companies provide higher profit or greater performance, auditors tend to provide less disclosure of their opinions on auditing report (Ousubcharoenchai, 2005). However, Ishak and Abidin (2018) could not find any influence of return on asset (ROA) on the audit reporting of listed companies in Malaysia. Therefore, this study hypothesises:

H2: There is a negative relationship between profitability and the level of KAM reporting.

Corporate complexity is a complexity of business processes, structures, systems, infrastructures, facilities, products, services, interfaces, and procedures that are required to complete in industry and internationalisation (Bushman, Chen, Engel, \& Smith, 2004). In Thailand, corporate complexity is included by the Stock Exchange of Thailand using market capitalisation and the proportion of freefloat holder of not less than $20 \%$ of the paid-up capital (SET, 2018). This study has divided corporate complexity within two categories: SET100 group and NonSET100 group. Companies in the SET100 group are significantly more complex than companies in Non-SET100 group. SET100 companies are selected as the top 
100 market capitalisation securities and trading liquidity by the SET (2018). This is because companies in the SET100 group need to satisfy their stakeholder demands rather than the companies in the non-SET100 group. Many studies found an influence of corporate complexity on corporate information reporting (Bushman et al., 2004; Suttipun \& Nuttaphon, 2014; Suttipun, 2018). However, Maedee (2006) did not find any relationship between firm complexity and audit reporting. Therefore, this study tests the hypothesis:

H3: There is a relationship between corporate complexity and the level of KAM reporting.

Legitimacy theory implies that older companies tend to provide more information than shorter-age companies because they have amassed more number and variety of social and community groups (Suttipun \& Nuttaphon, 2014). With more corporate information disclosure, auditors tend to provide more audit reporting including KAM reporting (Pratoomsuwan \& Yolrabil, 2018). However, the results of the relationship between corporate age and information reporting including KAM reporting were mixed. For example, Suttipun and Nuttaphon (2014) found that Thai corporate age positively influenced corporate information reporting. Moreover, Cowen et al. (1987) found a positive relationship between corporate age and corporate social responsibility reporting because society and community have more expectations for older companies to satisfy them than younger companies. On the other hand, Choi (1999) found no relationship between both variables. Thus, this study tests the hypothesis:

H4: There is a positive relationship between corporate age and the level of KAM reporting.

It is expected that audit rotation is perceived to be an attempt to enhance audit quality and subsequently improve audit independence. The extended relationship between auditor and company may hinder the ability of auditors to perform highquality audit tasks (Salleh \& Jasmani, 2014). In Thailand, listed companies have to rotate their audit partners in every five accounting years following by regulation of the Stock Exchange of Thailand (SET) (2548). This is because audit rotation will indicate the transparency and erudition of auditors and their partners. Moreover, changing audit partners will provide investors with reliable information for decision-making. However, the results of the influence of audit rotation on KAM reporting is mixed (Velte, 2018; Maedee, 2006). On one hand, Velte (2018) and Salleh and Jasmani (2014) found a relationship between audit rotation and KAM reporting in the annual reports. On the other hand, Maedee (2006) found no influence of audit rotation on KAM reporting because audit companies use similar standards to audit their partners' activities and actions. Therefore, to test for mixed results of previous studies, this study hypothesises:

H5: There is a relationship between audit rotation and the level of KAM reporting.

\section{Methods}

To investigate the level of KAM reporting in the annual reports, and examine the factors influencing KAM reporting, this study sampled 549 companies listed on the Stock Exchange of Thailand (SET) from 2016 to 2018 (SET, 2018). However, this study did not include companies that (i) issued no annual reports between 2016 
and 2018, (ii) did not end their accounting year on 31 December, (iii) were registered in the Market for Alternative Investment of Thailand (MAI), (iv) were registered as listed companies after 2016, (v) were registered in all financial industries and property fund and REITs section of the property and construction industry from the Stock Exchange of Thailand, and (vi) were withdrawn from listing by the SET including companies under rehabilitation.

There were 298 listed companies after considering the conditions above. By simple random sampling, 150 companies were used as a sample. To study KAM reporting in the annual reports, this study relied on 2016 to 2018 annual reports of the companies sampled resulting in 450 corporate annual reports (150 companies $x 3$ years $=450$ ). Annual reports from 2016 to 2018 were used to collect the data in this study. This is because the annual reports contained auditor reports. Moreover, the annual report is a statutory report which is widely recognised as the principal means for corporate communication of actions and activities (Suttipun, 2018). To investigate KAM reporting, the study focused on the key audit matters paragraph in the auditor reports which are in the annual reports of samples.

The variables' instruments were constructed into two sections which are the level of KAM reporting, and corporate characteristics. To measure variables used in the study, content analysis by checklist and word counting was employed to quantify the level of KAM reporting in corporate annual reports from 2016 to 2018. Content analysis was used in the study to allow replicable and valid influence to be drawn from data according to the context (Krippendorf, 1980).

To test for factors influencing the level of KAM reporting in the annual reports, corporate characteristics were assessed by the size of the company (Taylor \& Liu, 2008; Boonyanet \& Promsen, 2018) measured by sales, profitability measured by ROA (Ishak \& Abidin, 2018; Velte, 2018; Ousubcharoenchai, 2005), corporate complexity measured by dummy variable as $1=$ SET100 companies, and $0=$ NonSET100 companies (Bushman et al., 2004; Suttipun \& Nuttaphon, 2014), corporate age by year of firm (Suttipun \& Nuttaphon, 2014), and audit rotation by dummy variable as 1 = having audit rotation during period being study, and $0=$ having no audit rotation during period being study (Velte, 2018; Maedee, 2006).

Table 1. Measurement of Variables

\begin{tabular}{lcl}
\hline Variable & Notation & Measurement \\
\hline 1. KAM reporting (Issue) & ISSUE & Content analysis by checklist \\
2. KAM reporting (Word) & WORD & Content analysis by word counting \\
3. Size of the company & SIZE & Sales (Million baht) \\
4. Corporate Profitability & PROFIT & Return on asset (ROA) \\
5. Corporate Complexity & SET100 & $\begin{array}{l}\text { Dummy variable: } 1=\text { SET100 companies, } 0=\text { Non- } \\
\text { SET100 companies }\end{array}$ \\
6. Corporate Age & AGE & Year of companies \\
7. Audit rotation & AUDIT & $\begin{array}{l}\text { Dummy variable: } 1=\text { Audit rotation, } 0=\text { Non-audit } \\
\text { rotation }\end{array}$ \\
\hline
\end{tabular}

Table 1 indicates the methods of measuring the variables used in this study. Finished data were analysed by using the Statistic Software Program SPSS version 23. The data were analysed based on descriptive analysis and multiple regression. Descriptive analysis was used to investigate the level of KAM reporting in the 
annual reports of the sampled companies. Studies commonly use descriptive analysis using frequency, percentage, mean, and standard deviation to investigate corporate mandatory and voluntary reporting (Islam \& Deegan, 2010, Suttipun, 2018, Suttipun \& Nuttaphon, 2014).

Multiple regression was used to examine the relationship between corporate characteristics and KAM reporting. Studies typically use multiple regression to test the corporate characteristics influencing corporate information reporting (Branco \& Rodrigues, 2008, Gunno \& Penawuthikul, 2018). Finally, independent sample t-test was used to compare the different levels of KAM reporting in the annual report between SET100 companies and non-SET100 companies as well as audit rotation and non-audit rotation. There were two equations used in this study.

$W O R D=a+b 1 S I Z E+b 2$ PROFIT $+b 3 S E T 100+b 4 A G E+b 5 A U D I T+e$

(Main model)

ISSUE $=a+b 1 S I Z E+b 2 P R O F I T+b 3 S E T 100+b 4 A G E+b 5 A U D I T+e$ (Robustness test)

\section{Findings and Discussions}

To investigate the level of KAM reporting in the annual reports of 150 companies listed on the Stock Exchange of Thailand (SET) from 2016 to 2018, Table 2 the indicates results from the descriptive analysis. In terms of KAM reporting, the average reporting was nearly two issues for each company. The most common issue of KAM reporting in the annual report of the sampled companies was revenue recognition following by inventory, receivable allowance, property valuation, and asset impairment. Moreover, there was a fluctuation of KAM reporting in terms of the number of issues and level during the study period. They were increased from 2016 to 2017, and dropped from 2017 to 2018.

The result of this study was similar with Pratoomsuwan and Yolrabil (2018) and FAP (2016) whereby the most common KAM reporting was revenue recognition, inventory, receivable and allowance, property valuation, asset impairment, investment and investment impairment, goodwill impairment, taxation, and provision. Moreover, the results found that auditors still disclosed the same issues of KAM information in audit reports from 2016 to 2018, which support Gunno and Penawuthikul (2018). The main reason of similar reporting is that it is hard for auditors using their opinions reporting KAM information because they need to understand all the corporate conditions to consider the most significant risks for that period (Metheesuwapab, 2018).

Table 2. The level of KAM reporting

\begin{tabular}{lcccccccc}
\hline & \multicolumn{2}{c}{2016} & \multicolumn{2}{c}{2017} & \multicolumn{2}{c}{2018} & \multicolumn{2}{c}{ Average } \\
\cline { 2 - 9 } Variables & Mean & SD & Mean & SD & Mean & SD & Mean & SD \\
\hline ISSUE & 1.847 & .960 & 2.033 & .999 & 2.000 & 1.016 & 1.958 & .886 \\
WORD & 712.946 & 392.954 & 801.953 & 473.808 & 755.186 & 448.737 & 756.686 & 402.662 \\
\hline
\end{tabular}


Table 3 compares the independent sample t-test for the different levels of KAM reporting on the groups of SET (SET100 companies and non-SET100 companies) and audit rotation (rotation and non-rotation). There was a significant difference in the level of KAM reporting in both word count and issue number between SET100 companies (964.050 words and 2.316 issues) and non-SET100 companies (618.444 words and 1.718 issues) at the .01 level, while there was a significant difference in the level of KAM reporting between audit rotation (791.400 words and 2.067 issues) and non-audit rotation (678.203 words and 1.710 issues) at the .05 level.

Table 3. Independent Sample t-test

\begin{tabular}{lccccc}
\hline WORD & $\mathrm{N}$ & Mean & $\mathrm{SD}$ & $\mathrm{t}$ & Sig. \\
\hline SET100 Group & 150 & & & & \\
$\quad$ SET100 & 60 & 964.050 & 488.105 & 5.661 & $.000^{* *}$ \\
$\quad$ Non-SET100 & 90 & 618.444 & 255.323 & & \\
AUDIT Rotation & 150 & & & & \\
$\quad$ No rotation & 104 & 791.400 & 442.681 & 2.885 & $.032^{*}$ \\
$\quad$ Rotation & 46 & 678.203 & 281.469 & & Sig. \\
\hline ISSUE & $\mathrm{N}$ & Mean & SD & $\mathrm{t}$ & $.000^{* *}$ \\
\hline SET100 Group & 150 & & & & \\
$\quad$ SET100 & 60 & 2.316 & .999 & 4.277 & $.011^{*}$ \\
$\quad$ Non-SET100 & 90 & 1.718 & .713 & & \\
AUDIT rotation & 150 & & & & \\
$\quad$ No rotation & 104 & 2.067 & .938 & 2.573 & \\
$\quad$ Rotation & 46 & 1.710 & .704 & & \\
\hline
\end{tabular}

The levels of KAM reporting between SET100 companies and non-SET100 companies were similar to Pratoomsuwan and Yolrabil (2017) that SET100 companies provide more KAM reporting in their annual reports than non-SET100 companies. SET100 companies disclose more information to reduce political and legal exposure and enhance the level of transparency (Land \& Lundholm, 2000). There are complex businesses and longer risk description of SET100 companies rather than Non-SET100 companies. The different levels of KAM reporting between groups of interest in this study are due to the different levels of KAM reporting to respond to social and community expectations (De Villiers \& Van Standen, 2006; Islam and Deegan, 2010).

Table 4. Correlation Matrix

\begin{tabular}{lccccccc}
\hline & WORD & ISSUE & SIZE & PROFIT & SET100 & AGE & AUDIT \\
\hline WORD & 1 & & & & & & \\
ISSUE & $.705^{* *}$ & 1 & & & & & \\
SIZE & $.400^{* *}$ & $.314^{* *}$ & 1 & & & & \\
PROFIT & -.076 & -.054 & .056 & 1 & & & \\
SET100 & $-.422^{* *}$ & $-.332^{* *}$ & $-.313^{* *}$ & $-.228^{* *}$ & 1 & & \\
AGE & $.367^{* *}$ & $.266^{* *}$ & $.293^{* *}$ & .090 & $-.739^{* *}$ & 1 & \\
AUDIT & -.130 & $-.186^{*}$ & -.147 & .016 & .425 & $-.310^{* *}$ & 1 \\
\hline Mean & 756.686 & 1.958 & 48243.409 & 6.831 & .400 & 21.106 & .306 \\
SD & 402.662 & .886 & 18407.389 & 6.625 & .191 & 2.490 & .062 \\
VIF & - & - & 1.128 & 1.101 & 2.668 & 2.305 & 1.230 \\
\hline
\end{tabular}

** is significant at .01 , and * is significant at .05 
Multiple regression analysis requires the assumption that the data used is normally distributed with no multicollinearity problem among the variables used in the study. Table 4 indicates that a correlation matrix was used to test for multicollinearity between the seven variables used in this study, consisting of two dependent variables and five independents. Based on a fixed-effects model for panel testing, the variance inflation factor (VIF) of the correlation matrix between the variables was 2.668, which indicates that there was no multicollinearity which would be indicated by a VIF exceeding 10 (Gunno \& Penawuthikul, 2018; Vanstraelen et al., 2012). The low coefficients in the correlation matrix between the variables used in the study indicated that multicollinearity was unlikely to be a problem in the multiple regression (Suttipun, 2018). Thus, the multicollinearity problem does not exist in this study. Based on the correlation coefficients between the seven variables used in this study, there was a significantly positive correlation between WORD, SIZE, and AGE at the .01 level, while WORD had a significantly negative correlation with SET100 at the .01 level.

Table 5. Multiple Regression

\begin{tabular}{lcccc}
\hline \multirow{2}{*}{ Variables } & \multicolumn{2}{c}{ Main model } & \multicolumn{2}{c}{ Robustness test } \\
\cline { 2 - 5 } & $\mathrm{B}$ & $\mathrm{t}$ (sig.) & $\mathrm{B}$ & $\mathrm{t}$ (sig.) \\
\hline Constant & 617.313 & $11.529^{* *}$ & 1.820 & $14.281^{* *}$ \\
SIZE & .001 & $3.942^{* *}$ & $1.112 \mathrm{E}-6$ & $2.891^{* *}$ \\
PROFIT & -8.593 & $-2.522^{*}$ & -.013 & $-2.648^{*}$ \\
SET100 & 306.336 & $3.275^{* *}$ & .505 & $2.270^{*}$ \\
AGE & .982 & .476 & .000 & -.063 \\
AUDIT & 78.534 & 1.157 & -.064 & -.398 \\
\hline R square & \multicolumn{3}{c}{.177} \\
Adj. R square & \multicolumn{3}{c}{.295} & \multicolumn{3}{c}{$6.192^{* *}$} \\
F-value (sig.) & \multicolumn{3}{c}{$12.057^{* *}$}
\end{tabular}

** is significant at .01 , and ${ }^{*}$ is significant at .05

On the other hand, there was a significantly positive correlation between ISSUE and AGE at the .01 level, while ISSUE had a significantly negative correlation with SET100 and AUDIT at .01 and .05 levels. Table 5 shows the outcome of the multiple regression analysis testing the relationship between corporate characteristics and the level of KAM reporting in the annual reports. As the results in the main model, SIZE and SET100 had a positive and significant influence on the level of KAM reporting at the .01 level, while there was a negative influence of PROFIT on the level of KAM reporting at the 05 level. However, AGE and AUDIT had no influence on KAM reporting at the .05 level. In terms of company size, the result of this study was consistent with Taylor and Liu (2008) and Velte (2018) who found a positive influence of company size on KAM reporting. Based on legitimacy theory, larger companies are interested in their activities and actions including reporting by social expectations rather than smaller companies (Taylor and Liu, 2008). Moreover, larger companies have more audit activities than smaller companies. As such, audit reporting on larger companies tends to disclose more common than smaller companies (Velte, 2018). In terms of corporate complexity, the result was consistent with Bushman et al. (2004) and Suttipun and Nuttaphon (2014) because the companies in the SET100 
group need to satisfy their social expectations rather than the companies in the non-SET100 group. In more detail, corporate complexity in Thailand was included in the Stock Exchange of Thailand using market capitalisation and the proportion of free-float holder of not less than $20 \%$ of the paid-up capital (SET, 2018).

Companies in the SET100 group are significantly more complex than companies in the non-SET100 group. If more complex companies incur more difficult audit activities than less complex companies, auditors will disclose more opinion on their audit reporting (Boonlert-U-Thai et al., 2019). In terms of profitability, the result was similar to Velte (2018) and Ousubcharoenchai (2005) that there was a negative influence of profitability measured by ROA on KAM reporting. When companies experience reduced loss or profit, it was caused by the higher risk that affects audit reporting (Velte, 2018). It means auditors need to provide more information and disclosure of their opinions to corporate changes and risks to respond to social and community expectation. On the other hand, the auditors would tend to provide less reporting of their opinion on audit reporting if the companies had a higher profit or greater performance (Ousubcharoenchai, 2005).

The study found no influence of corporate age and audit rotation on KAM reporting of companies listed on the SET. In terms of corporate age, the result was consistent with Choi (1999) who found no relationship between corporate age and information reporting. Choi (1999) argued that the maturity of corporations could result in higher levels of reputational risk. Therefore, companies engaged in more actions and activities.

In terms of audit rotation, the result of this study was similar to Maedee (2006) who found no influence of audit rotation on KAM reporting of Thai listed companies. This is because audit companies use similar standards to audit their partners' activities and actions. Table 5 shows the test of robustness model. The results were similar with the main model. Therefore, the results of this study accept $\mathrm{H} 1, \mathrm{H} 2$, and $\mathrm{H} 3$, while $\mathrm{H} 4$ and $\mathrm{H} 5$ were rejected.

\section{Summary and Suggestion for Future Study}

The study investigated the level of KAM reporting in the annual reports of companies listed on the Stock Exchange of Thailand (SET) from 2016 to 2018 and examined the factors influencing KAM reporting. KAM reporting was 756.686 average words within 1.958 issues in corporate annual reports. There was a significantly different level of KAM reporting between SET100 and non-SET100 companies as well as between audit rotation and non-audit rotation. Moreover, there was a significantly positive influence of firm size and SET group on the level of KAM reporting in the annual reports from 2016 to 2018, while profitability had a negative influence on the level of KAM reporting. This study found no significant influence of corporate age and audit rotation on the level of KAM reporting.

The study's findings provide several contributions. This is the first longitudinal study of KAM reporting in Thailand from 2016 to 2018. The results shed light on the level of the early state of KAM reporting in Thailand by auditors. Further, the study expanded the literature on the mandatory KAM reporting of information in emerging economies. Moreover, the study used legitimacy theory 
as the theoretical framework because the theory can explain the reason for KAM reporting of Thai listed companies as a reaction to external pressures from social expectations. For example, the theory postulates that large and complex companies with higher KAM reporting were more visible than small and noncomplex companies because of more social and community expectation. On the other hand, when companies experience loss or less profit, society and community will be more concerned.

In terms of practical contributions, investors can consider for decision-making from the corporate characteristics affecting KAM reporting. Next, regulators and policymakers consisting of SET and FAP become aware of the implications of KAM reporting in Thailand as good corporate governance from listed companies as well as the other developed countries.

Limitations should be mentioned in this study. First, within two capital markets in Thailand, this study examined only the Stock Exchange of Thailand (SET), but not for the Alternative Market for Investment (MAI). Second, even though several corporate characteristics are influencing KAM reporting, the study used five variables in Thailand. Third, longitudinal study within three years of this investigation could be regarded as a limitation. Finally, the study did not consider the influence of external auditor characteristics on KAM reporting such as type of auditor (Big 4 or Non-Big 4 auditors), audit fee, ownership status of auditor (international or local auditors), and audit gender. This is because KAM reporting can be affected by both corporate characteristics and external auditor characteristics. To address these limitations, future study could investigate and test other corporate characteristics i.e. audit type (Big4 and Non-big4 auditors), leverage, liquidity, and corporate governance rate and external auditor characteristics i.e. auditor (Big 4 or Non-Big 4 auditors), audit fee, audit rotation, ownership status of auditor (international or local auditors), and audit gender affecting KAM reporting in both SET and MAI.

\section{References}

Bedard, J., Gonthier-Besacier, N., \& Schatt, A. (2015). Analysis of the consequences of the disclosure of key audit matters in the audit report. The 2015 Audit \& Assurance (BAFA) Conference, Edinburgh, United Kingdom.

Boonlert-U-Thai, K., Srijunpetch, S., \& Phakdee, A. (2019). Key audit matters: what they tell. $\begin{array}{llll}\text { Journal of Accounting Profession, } & \text { 15(45), } 25 .\end{array}$ https://doi.nrct.go.th//ListDoi/listDetail?Resolve_DOI=10.14456/jap.2019.1

Boonyanet, W., \& Promsen, W. (2018). Key Audit Matters: Just Little Informative Value to Investors in Emerging Markets? Chulalongkorn Business Review, 41(2), 153-183. https://doi.nrct.go.th//ListDoi/listDetail?Resolve_DOI=10.14456/cbsr.2019.6

Branco, M.C., \& Rodrigues, L.L. (2008). Factors influencing social responsibility disclosure by Portuguese companies. Journal of Business Ethics, 83(2), 685-701. https://doi:10.1007/s10551007-9658-z

Brown, H.S., DeJong, M., \& Levy, D.L. (2009). Building institutions based on information disclosure: lessons from GRI's sustainable reporting. Journal of Cleaner Production, 17(3), 57158. https:// doi.org/10.1016/j.jclepro.2008.12.009

Bushman, R., Chen, Q., Engel, E., \& Smith, A. (2004). Financial accounting information, organizational complexity and corporate governance systems. Journal of Accounting and Economics, 37(2), 167-201. https://doi.org/10.1016/j.jacceco.2003.09.005 
Cowen, S.S., Ferreri, L.B., \& Parker, L.D. (1987). The impact of corporate characteristics on social responsibility disclosure: a typology and frequency-based analysis. Accounting, Organizations and Society, 12(2), 111-122. https:// doi.org/10.1016/0361-3682(87)90001-8

Choi, J.S. (1999). An investigation of the initial voluntary environmental disclosures made in Korean semi-annual financial reports. Pacific Accounting Review, 11(3), 73-102. https:// doi.org/10.1016/S2212-5671(12)00059-7

De Villiers, C., \& Van Staden, C.J. (2006). Can less environmental disclosure have a legitimizing effect? Evidence from Africa. Accounting, Organizations and Society, 31(8), 763-781. https:// doi: 10.1016/j.aos.2006.03.001

Deegan, C. (2002). Introduction: the legitimacy effect of social and environmental disclosures: a theoretical foundation. Accounting, Auditing and Accountability Journal, 15(3), 282-311. https://doi.org/10.1016/j.aos.2006.03.001

Federation of Accounting Profession (FAP) of Thailand. (2016). Auditor's view on key audit matter. Retrieved from http://www.tfac.or.th/

Gray, R., Kouhy, R., \& Lavers, S. (1995). Corporate social and environmental reporting: a review of the literature and a longitudinal study of UK disclosure. Accounting, Auditing and Accountability Journal, 8(2), 47-77. https:// doi.org/10.1108/09513579510146996

Gunno, P., \& Penawuthikul. P. (2018). Factors affecting disclosure quality on key audit matters in auditor's report in Thailand. Journal of MCU Nakhondhat, 5(3), 926-942. https://www.tcithaijo.org/index.php/JMND/article/view/141713/119111

International Auditing and Assurance Standards Board (IAASB). (2011). Enhancing the value of auditor reporting: exploring options for change (Consultation Paper). Retrieved from https://www.ifac.org/

Ishak, Z., \& Abidin, S. (2018). The Impact of Enhanced Communication Requirement and other Determinants on Audit Fees. Knowledge Management International Conference (KMICe) Malaysia, 223-228. http:// repo.uum.edu.my/id/eprint/25228

Islam, M., \& Deegan, C. (2010). Media pressures and corporate disclosure of social responsibility performance information: a study of two global clothing and sports retail companies. $\begin{array}{llll}\text { Accounting } \text { and } \text { Business } & \text { 131-148. }\end{array}$ https://doi.org/10.1080/00014788.2010.9663388

Joshi, P.L., \& Gao, S.S. (2009). Multinational corporate social and environmental disclosures (CSED) on websites. International Journal of Commerce and Management, 19(1), 27-44. https://doi.org/10.1108/10569210910939654

Krippendorf, K. (1980). Content analysis: an introduction to its methodology. Sage, New York.

Land, M.H., \& Lundholm, R.J. (2000). Voluntary disclosure and equity offerings: reducing information asymmetry or hyping the stock? Contemporary Accounting Research, 17(4), 623-662. https:// doi.org/10.1506/9N45-F0JX-AXVW-LBWJ

Maedee, M. (2006). The relationship among auditor tenure, audit firm size, auditor change and going concern audit reports on listed companies in the Stock Exchange of Thailand. Master Thesis of Accountancy Program, Chulalongkorn University, Bangkok.

Matheesuwapab, S. (2018). The nature in reporting of the key Audit Matters (KAM): the judgment in writing key audit matter of certified public accountant from big four accounting firms. $\begin{array}{lll}\text { Suthiparithat Journal, 210-222. } & \text { 32(104), }\end{array}$ https://www.dpu.ac.th/dpurc/assets/uploads/magazine/dx8y8jd94xwgskskk.pdf

Ousubcharoenchai, T. (2005). The relationship between earning quality and auditors reports. Master Thesis of Accountancy Program, Chulalongkorn University, Bangkok.

Porter, B., Hogartaigh, C.O., \& Baskerville, R. (2009). Report on research conducted in the United Kingdom and New Zealand in 2008 investigating the audit expectation-performance gap and users' understanding of, and desired improvements to, the auditor's report. Report Prepared for AICPA's ASB and IAASB. Retrieved from https://www.ifac.org/

Pratoomsuwan, T., \& Yolrabil, O. (2018). The key Audit Matters (KAM) practices: the review of first year experience in Thailand. NIDA Business Journal, 23(1), 63-91. http:// mba.nida.ac.th/en/books/read/871508c0-ff6c-11e8-a073-0f7c1d912d55

Pries, F., \& Scott, S. (2018). Costs and benefits of key audit matter reporting for smaller public entities: The Australian experience. College of Business and Economics, University of Guelph, Canada, 31(2), 1-9. 
Salleh, K., \& Jasmani, H. (2014). Audit rotation and audit report: empirical evidence from Malaysian PLCs over the period of ten years. Procedia-Social and Behavioral Sciences, 145(1), $40-$ 5. https://doi.org/10.1016/j.sbspro.2014.06.009

Srijunpetch, S. (2017). Key audit matters in an auditor's report and response of the Stock Exchange of Thailand. Journal of Accounting Profession, 13(38), 22-37. http:/ / doi: 10.14456/jap.2017.11

Suttipun, M. (2018). Association between board composition and intellectual capital disclosure: an evidence from Thailand. Journal of Business Administration, 41(160), 74-97. http://doi: 10.14456/jba.2018.19

Suttipun, M., \& Nuttaphon, C. (2014). Corporate social responsibility reporting on websites in Thailand. Kasetsart Journal of Social Sciences, 35(3), 536-549.

Tangruenrat, C. (2015). The value of new auditor's report. Journal of Accounting Profession, 11(31), 26-44. http:/ / doi: 10.14456/jap.2015.9

Taylor, D., \& Liu, J. (2008). Legitimacy and corporate governance determinants of executives' remuneration disclosures. Corporate Governance, 8(2), 59-72. https://doi.org/10.1108/14720700810853400

The Stock Exchange of Thailand (SET). (2018). Company listed in the Stock Exchange of Thailand. Retrieved from https://www.set.or.th/

Vanstraelen, A., Schelleman, C., Meuwissen, R., \& Hofmann, I. (2012). The audit reporting debated seemingly intractable problems and solutions. European Accounting Review, 21(2), 193-215. https://doi.org/10.1080/09638180.2012.687506

Velte, P. (2018). Does gender diversity in the audit committee influence key audit matters' readability in the audit report? UK evidence. Corporate Social Responsibility and Environmental Management, 25(3), 748-755. https:// doi.org/10.1002/csr.1491 